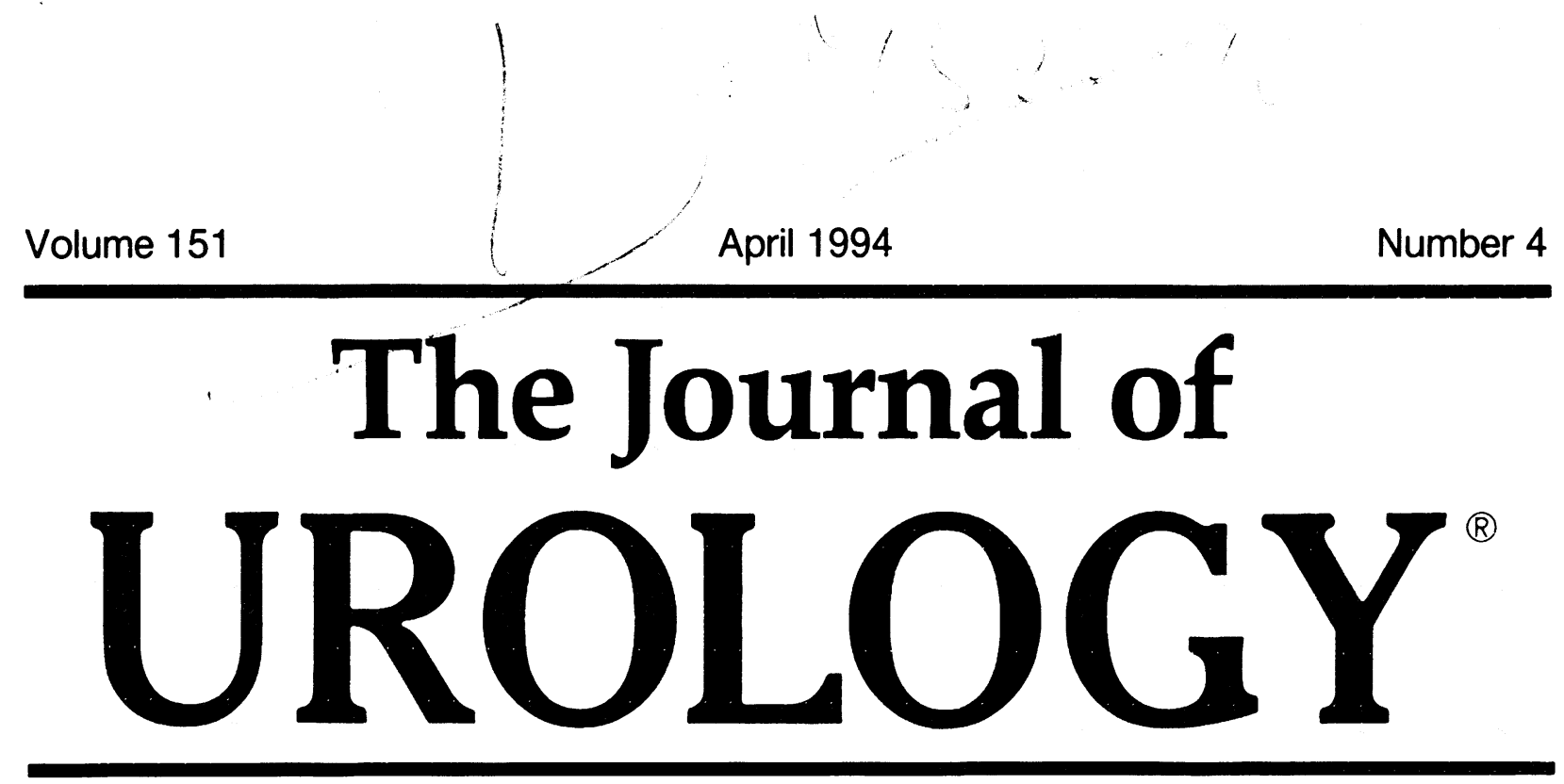

Official Journal of the American Urological Association, Inc. Founded In 1917 By Hugh Hampton Young

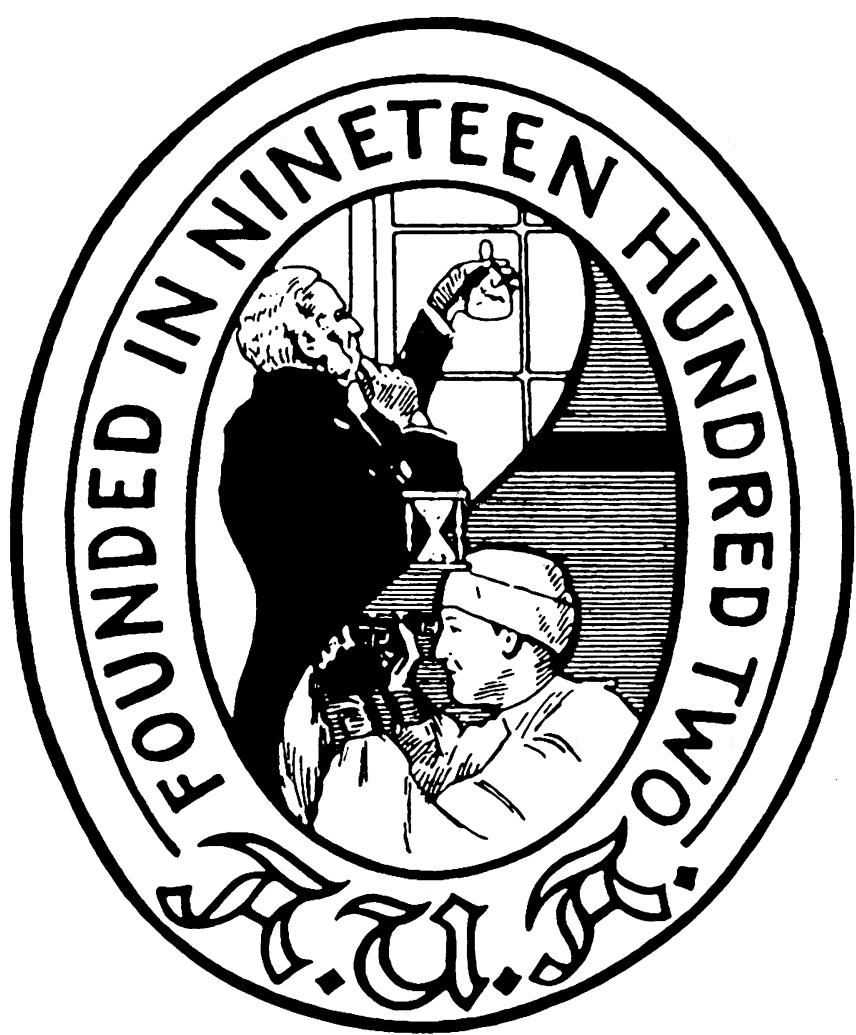

Annual Meeting, American Urological Association, Inc., San Francisco, California, May 14-19, 1994 


\section{The Journal of \\ UROLOGY}

Volume 151

April 1994

Number 4

\section{Review Article}

CLINICAL UROLOGY

Carcinoma In Situ of Penis. G. S. Gerber

\section{Original Articles}

Effect of High Dose Vitamin C on Urinary Oxalate Levels. T. R. Wandzilak, S. D. D'Andre, P. A. Davis and H. E. Williams

Regional Variation in Nephrolithiasis Incidence and Prevalence Among United States Men. G. C. Curhan, E. B. Rimm, W. C. Willett and M. J. Stampfer

Ureteroscopic Fragmentation Followed by Extracorporeal Shock Wave Lithotripsy: Treatment Alternative for Selected Large or Staghorn Calculi. S. P. Dretler

Presentation, Diagnosis and Treatment of Renal Abscesses: 1972-1988. J. E. Fowler, Jr. and T. Perkins . .

Endoscopic Infundibulotomy in Tuberculous Renal Infundibular Stricture. T.-K. Hwang and Y.-H. Park

Transplant Nephrectomy Over 20 Years: Factors Involved in Associated Morbidity and Mortality. $D$. C. O'Sullivan, D. M. Murphy, P. McLean and M. G. Donovan

Symptomatic Cholelithiasis Following Continent Urinary Diversion Using Ileocolonic Bowel Segments. $A$. J. Kirsch and T. W. Hensle

Ileocecal Valve Reconstruction During Continent Urinary Diversion. M. Fisch, $R$. Wammack, F. Spies, S. C. Müller, A. Mokthar, M. Ghoneim and R. Hohenfellner

Complications of Exaggerated Lithotomy Position: Review of 177 Cases. $K W$ Angermeier and $G$. Jordan

Analysis of Factors Contributing to Success or Failure of 1-Stage Urethroplasty for Urethral Stricture Disease. C. G. Roehrborn and J. D. McConnell

Urethral Meatal Warts in Men: Results of Urethroscopy and Biopsy. I. Rothman, R. E. Berger, N. Kiviat,

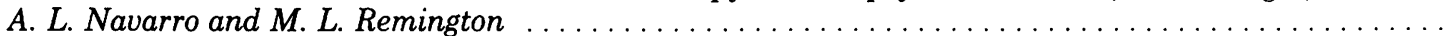

Oral Terbutaline for Treatment of Priapism. F. E. Govier, E. Jonsson and D. Kramer-Levien . . . . . .

Prognostic Factors for Postoperative Outcome of Penile Venous Surgery for Venogenic Erectile Dysfunction. C. G. Stief, M. Djamilian, M. C. Truss, H. Tan, W. F. Thon and U. Jonas . . . . . . . . . .

Erectile Dysfunction in Diabetic Men: Neurological Factor Revisited. B. L. H. Bemelmans, E. J. H. Meuleman, W. H. Doesburg, S. L. H. Notermans and F. M. J. Debruyne

Editorial: Erectile Dysfunction Associated With Cavernous and Neurological Disorders. T. F. Lue

842

847

852

855

861

866

Post-Vasectomy Length of Testicular Vasal Remnant: Predictor of Surgical Outcome in Microscopic Vasectomy Reversal. M. A. Witt, S. Heron and L. I. Lipshultz

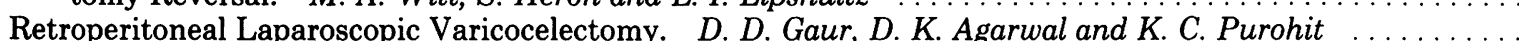

Polidocanol Sclerotherapy for Hydroceles and Epididymal Cysts. T. Sigurdsson, J. E. Johansson, S. Jahnson, $F$. Helgesen and S. O. Andersson

Safety of Transurethral Surgery in Early Postoperative Period Following Open Cardiac Procedure. $S$. J. Rowe, A. J. Thomas, Jr., D. A. Goldfarb, E. A. Klein, D. K. Montague, S. B. Streem and A. C. Novick . .

Laparoscopic Pelvic Lymphadenectomy and Radical Perineal Prostatectomy: Viable Alternative to Radical Retropubic Prostatectomy. D. A. Levy and M. I. Resnick

Collagen Cross-Link Metabolites in Urine as Markers of Bone Metastases in Prostatic Carcinoma. $K$ Miyamoto, S. A. McSherry, S. P. Robins, J. M. Besterman and J. L. Mohler . . . . . . . . . . . . . . .

Neuroendocrine Differentiation in Metastatic Prostatic Adenocarcinoma. A. G. Aprikian, C. Cordon-Cardo, W. R. Fair, Z.-F. Zhang, M. Bazinet, S. M. Hamdy and V. E. Reuter . . . . . . . . . . . . . . .

Myocutaneous Flaps in Genitourinary Oncology. P. Russo, E. F. Saldana, S. Yu, T. Chaglassian and D. A. Hidalgo

Laparoscopic Renal Biopsy via Retroperitoneal Approach. D. D. Gaur, D. K. Agarwal, M. V. Khochikar and K C. Purohit

Retroperitoneal Laparoscopic Pyelolithotomy. D. D. Gaur, D. K. Agarwal, K. C. Purohit and A. S. Darshane.

Open Surgical Revision of Laparoscopic Pelvic Lymphadenectomy for Staging of Prostate Cancer: Impact of Laparoscopic Learning Curve. G. Guazzoni, F. Montorsi, F. Bergamaschi, P. Bellinzoni, A. Centemero, $P$. Consonni and P. Rigatti

Long-Term Results and Late Recurrence After Endoureteropyelotomy: Critical Analysis of Prognostic Factors. P. J. Van Cangh, J. F. Wilmart, R. J. Opsomer, A. Abi-Aad, F. X. Wese and F. Lorge . . . .

Editorial: Laparoscopy. H. Y. Wong and D. P. Griffith 


\section{Urologists At Work}

Techniques to Negotiate Tortuous Ureter. D. M. Schwalb and M. Eshghi

Urethrovesical Anastomosis: Urethral Suturing Under Direct Vision. $R . O$. Fourcade $\ldots \ldots \ldots \ldots \ldots \ldots \ldots$

\section{Urological Neurology and Urodynamics}

Use of Intravesical Oxybutynin Chloride in Patients With Detrusor Hypertonicity and Detrusor Hyperreflexia. N. G. Kasabian, J. D. Vlachiotis, A. Lais, B. Klumpp, M. D. Kelly, M. B. Siroky and S. B. Bauer.

Role of Limited Evaluation and Aggressive Medical Management in Multiple Sclerosis: Review of 113 Patients. L. T. Sirls, P. E. Zimmern and G. E. Leach

Effect of Terazosin on Bladder Function in Spinal Cord Injured Patient. S. J. Swierzewski, III, E. A.

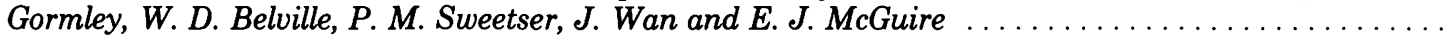

Bladder Compliance After Posterior Sacral Root Rhizotomies and Anterior Sacral Root Stimulation. $E$. $L$. Koldewijn, P. E. V. Van Kerrebroeck, P. F. W. M. Rosier, H. Wijkstra and F. M. J. Debruyne .........

Is Sphincterotomy Best Management of Spinal Cord Injured Bladder? J. M. Vapnek, D. R. Couillard and A. R. Stone

Editorial: Bladder Compliance. E. J. McGuire

\section{Case Reports}

Transcatheter Embolization of Large Idiopathic Renal Arteriovenous Fistula. W. S. Kearse, Jr., A. E. Joseph and E. S. Sabanegh, Jr.

Intraperitoneal Drainage of Recurrent Lymphoceles Using Internalized Tenckhoff Catheter. B. A. Lucas, I. S. Gill and L. C. Munch

Cystometrography Provides Previously Unrecognized Opportunity for Successful Management of Urinary Leaks After Renal Transplantation. A. Rana, M. F. Hand, G. D. Chisholm and J. L. Anderton .......

Acute Renal Failure Secondary to Ciprofloxacin Use. J. P. Connor, J. M. Curry, T. L. Selby and A. D. Perlmutter

Spontaneous Perinephric Hemorrhage in Middle-Aged Diabetic Woman. E. Zuckerman, I. Miselevitch, D.

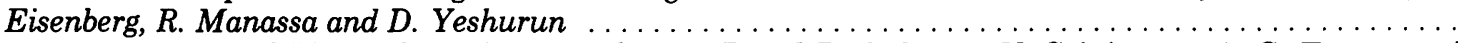

Massive Intraperitoneal Hemorrhage Associated With Renal Pathology. V. Srinivasan, A. G. Turner and H. N. Blackford

Renal Malacoplakia With Secondary Hepato-Duodenal Involvement. C.-S. Chen, M.-K. Lai, S. Hsueh, T.L. Hwang and C.-K. Chuang

Giant Renomedullary Interstitial Cell Tumor. K. T. Mai

Transitional Cell Carcinoma in Tuberculous Kidney: Case Report and Review of Literature. $D$. Feeney, $E$.

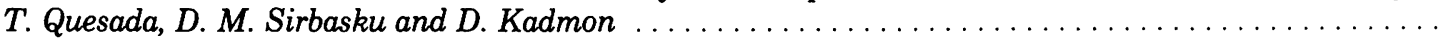

Splenic Rupture During Occlusion of Porta Hepatis in Resection of Tumors With Vena Caval Extension. $J$.

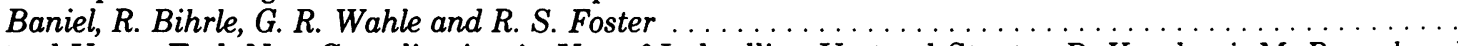

Knotted Upper End: New Complication in Use of Indwelling Ureteral Stent. P. Kundargi, M. Bansal and P. K. Pattnaik

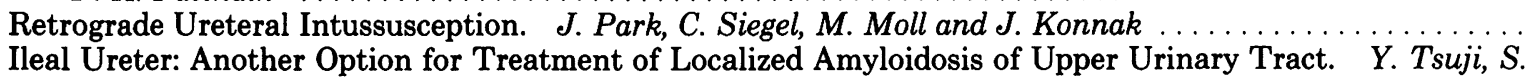
Michinaga and A. Ariyoshi

Retroperitoneal Laparoscopic Ureterolithotomy for Multiple Upper Mid Ureteral Calculi. D. D. Gaur, D. K.

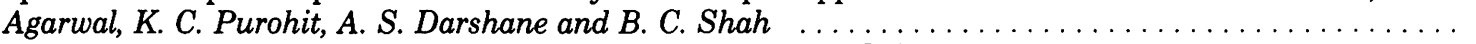

Laparoscopic Repair of Intraperitoneal Bladder Perforation. $R$. O. Parra $\ldots \ldots \ldots \ldots \ldots \ldots \ldots \ldots \ldots$

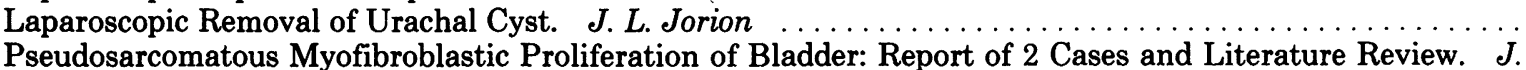

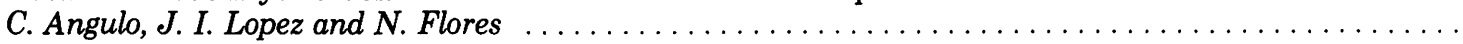

Hemorrhagic Cystitis Due to Adenovirus Infection Following Bone Marrow Transplantation. T. A. Londer-

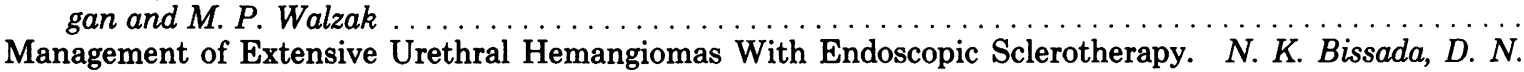

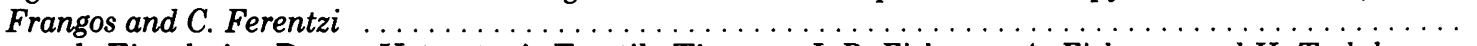

Retrograde Ejaculation Due to Heterotopic Erectile Tissue. J. R. Fishman, A. Fishman and H. Tesluk ... 1017

Intraoperative Arteriography Facilitates Penile Revascularization. R. L. Bare, A. DeFranzo and J. P. Jarow ... 1019

Familial Occurrence of Testicular Cancer. M. A. Cooper, J. Fellows and L. H. Einhorn . . . . . . . . . . 1022

Response of Metastasized Sex Cord Gonadal Stromal Tumor of Testis to Cisplatin-Based Chemotherapy. K.$P$. Dieckmann and V. Loy . . . . . . . . . . . . . . . . . . . . . . . . . . . . . . . . . . . . . . . . 1024

Leiomyoma of Seminal Vesicle. A. T. Gentile, H. S. Moseley, S. F. Quinn, D. Franzini and T. M. Pitre ... 1027

\section{Letters to the Editor}

Re: High Pressure Versus Low Pressure Electromagnetic Extracorporeal Lithotripsy, by H. Vandeursen, D. DeRidder, G. Pittomvils, R. Demeulenaere, D. Herremans, R. Boving and L. Baert. G. L. Mathes, Jr. _.. 1030

Re: Laparoscopic Ureterectomy: Initial Clinical Experience, by P. J. Chandhoke, R. V. Clayman, K. Kerbl, R. S. Figenshau, E. M. McDougall, L. R. Kavoussi and M. Stone. J. Palou and B. Xavier ......... 1030 
Re: Periurethral Polytetrafluoroethylene Paste Injection in Incontinent Female Subjects: Surgical Indications and Improved Surgical Technique, by R. Lotenfoe, J. K. O'Kelly, M. Helal and J. L. Lockhart. $P$. $A$. Dewan . . . . . . . . . . . . . . . . . . . . . . . . . . . . . . . . . . . . . . . . . . . . . . . . . . . . . . . . Lymph Node Dissection, by J. F. Danella, J. deKernion, R. B. Smith and J. Steckel. $\quad R$. P. Gibbons . . . . . 1031

\section{Erratum}

Urinary Tract Infection

\section{PEDIATRIC UROLOGY}

Prenatal and Postnatal Findings in Monochorionic, Monoamniotic Twins Discordant for Bilateral Renal Agenesis-Dysgenesis (Perinatal Lethal Renal Disease). B. G. Cilento, Jr., B. R. Benacerraf and J.

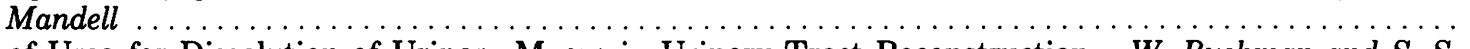

Use of Urea for Dissolution of Urinary Mucus in Urinary Tract Reconstruction. W. Bushman and $S$. $S$.

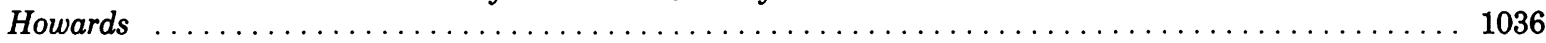

Urodynamic Evaluation of Children With Caudal Regression Syndrome (Caudal Dysplasia Sequence). $T$.

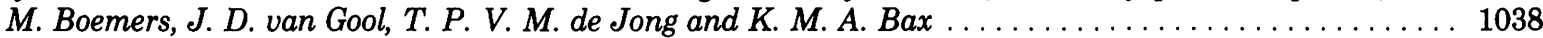

Preexisting Neurogenic Voiding Dysfunction in Children With Imperforate Anus: Problems in Management. H. Kakizaki, K. Nonomura, Y. Asano, Y. Shinno, K. Ameda and T. Koyanagi (Editorial Comment by S. P. Greenfield)

Early Cystometrograms Can Predict Response to Intravesical Instillation of Oxybutynin Chloride in Myelomeningocele Patients. J. P. Connor, G. Betrus, P. Fleming, A. D. Perlmutter and C. Reitelman . . . . 1045

Cutaneous Vesicostomy With Direct Intravesical Application of Formalin: Management of Severe Vesical Hemorrhage Resulting From High Dose Cyclophosphamide in Boys. J. F. Redman and M. Kletzel . 1048

Catheter Guide to Obviate Difficult Urethral Catheterization in Male Infants and Boys. J. F. Redman ... 1051

Urethral Valve Incision Using Modified Venous Valvulotome. W. J. Cromie, M. P. Cain, M. F. Bellinger, J.

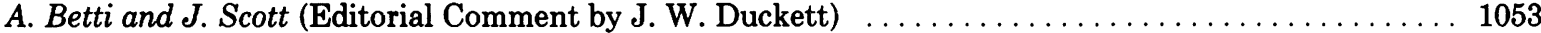

Long-Term Followup of Bladder Mucosa Graft for Male Urethral Reconstruction. T. M. Kinkead, P. A.

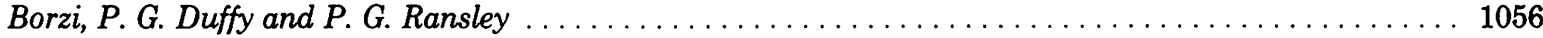

Distal Hypospadias Repair Without Stents: Is It Better? H. Buson, D. Smiley, Y. Reinberg and R. Gonzalez

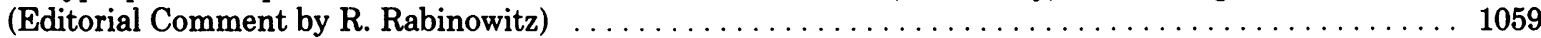

Congenital Fistula of Penile Urethra. M. L. Ritchey, A. Sinha and L. Argueso . . . . . . . . . . . . . . . 1061

Metastatic Testicular Choriocarcinoma and Secondary Hyperthyroidism: Case Report and Review of Litera-

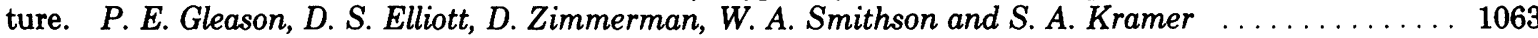

\section{INVESTIGATIVE UROLOGY}

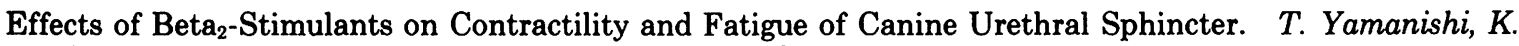

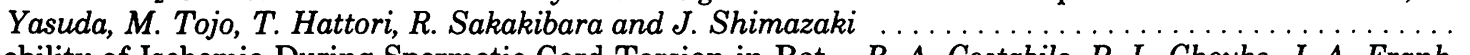

Variability of Ischemia During Spermatic Cord Torsion in Rat. R. A. Costabile, P. L. Choyke, J. A. Frank,

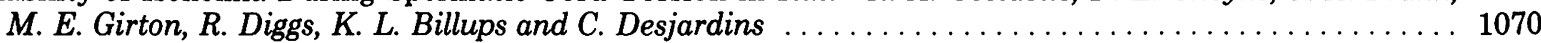

Somatic Allelic Loss at DCC, APC, nm23-H1 and p53 Tumor Suppressor Gene Loci in Human Prostatic

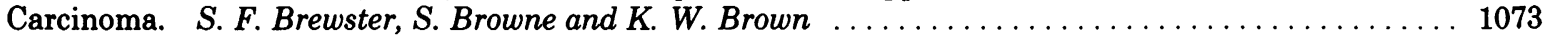

Suppression of Renal Scarring by Prednisolone Combined With Ciprofloxacin in Ascending Pyelonephritis in Rats. M. Haraoka, T. Matsumoto, K. Takahashi, S. Kubo, M. Tanaka and J. Kumazawa . . . . . . 1078

Latissimus Dorsi Muscle for Detrusor Assistance: Functional Recovery After Nerve Division and Repair. $B$. Von Heyden, J. P. Anthony, N. Kaula, G. B. Brock, G. Jakse and E. A. Tanagho . . . . . . . . . . . 1081

Effect of Urinary Diversion on Recovery of Micturition Reflexes After Spinal Cord Injury in Rat. $M$. $N$.

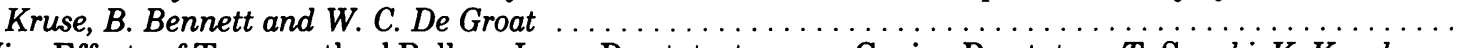

In Vivo Effects of Transurethral Balloon Laser Prostatectomy on Canine Prostate. T. Suzuki, K. Kurokawa,

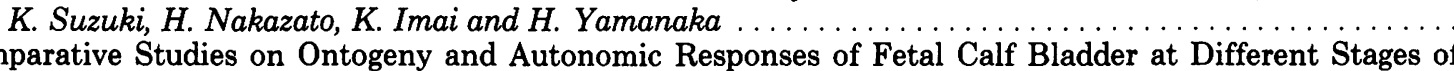
Development: Involvement of Nitric Oxide on Field Stimulated Relaxation. J. G. Lee, D. Coplen, E.

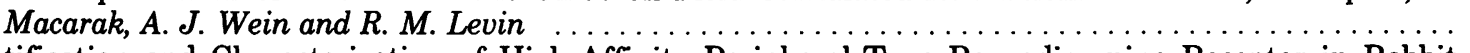

Identification and Characterization of High-Affinity Peripheral-Type Benzodiazepine Receptor in Rabbit

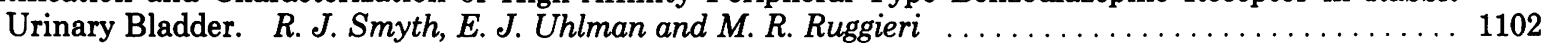

Effects of Nicorandil on Human Isolated Corpus Cavernosum and Cavernous Artery. P. Hedlund, F.

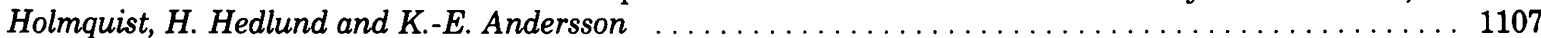

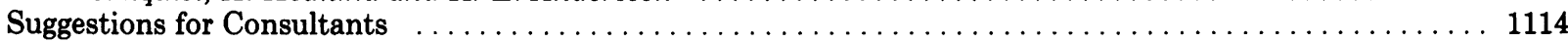




\section{UROLOGICAL SURVEY}

Benign and Malignant Neoplasms of Prostate. $\quad P . C$. Walsh $\ldots \ldots \ldots \ldots \ldots \ldots \ldots \ldots \ldots$

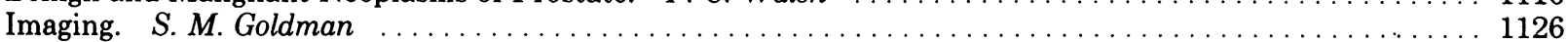

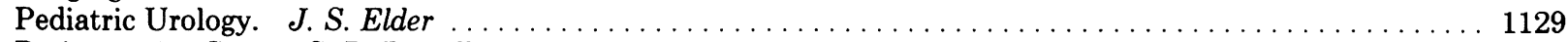

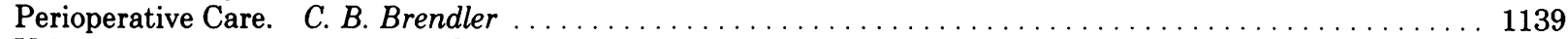

Urinary Tract Infection. $A . J$. Schaeffer $\ldots \ldots \ldots \ldots \ldots \ldots \ldots \ldots \ldots \ldots \ldots \ldots \ldots \ldots \ldots \ldots \ldots \ldots \ldots \ldots 1148$

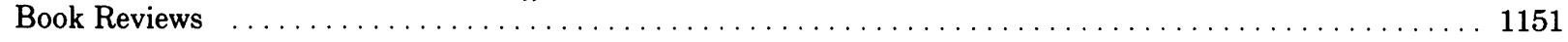

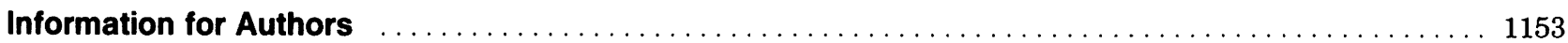

\section{PROPRIETARY NAMES}

Many of the words appearing in the JOURNAL OF UROLOGY are proprietary names even though no reference to this fact is made in the text. The appearance of any name without designation as proprietary is, therefore, not to be regarded as a representation by the editorial board or publisher that it is not the subject of proprietary rights.

\section{GUIDELINES FOR SUPPLEMENTS}

The Editors of the Journal will consider requests for and solicit sponsors of Supplements to The Journal of Urology. For those interested the following are the proposed steps for publication of a Supplement.

1) Proposal formulated by sponsors of the Supplement or solicited by the Journal Editorial Staff that would include an indication of the major topics with a limited outline of subtopics, the nature of the articles to be included (review, original papers with or without discussion), identification of a sponsoring group or individual, identification of the type of internal quality control group available for the Journal Editors to work with and an indication of the financial support available.

2) Response by the Editorial Staff with identification of a specific individual to work with the Editorial Committee of the sponsors.
3) Agree to a deadline for submission of the papers, number of papers and so forth.

4) Formulation of and agreement on procedure for initial screening and editorial evaluation of manuscripts and discussions with active participation by the sponsoring group.

5) Submission to the Editorial Staff of the Journal for their evaluation.

6) Interaction between Journal and sponsoring editorial group. Final decision is retained by Journal Editorial Staff.

7) Redaction, page proofing and so forth by Editorial Staff. Articles in supplements would be indexed in the Journal.

8) Publication.

\section{DISCLAIMER}

The statements and opinions contained in the articles of JOURNAL OF UROLOGY are solely those of the individual authors and contributors and not of the American Urological Association, Inc. or Williams \& Wilkins. The appearance of the advertisements in the Journal is not a warranty, endorsement or approval of the products or services advertised or of their effectiveness, quality or safety. The American Urological Association, Inc., and the Publisher disclaim responsibility for any injury to persons or property resulting from any ideas or products referred to in the articles or advertisements. 


\title{
PROGNOSTIC FACTORS FOR THE POSTOPERATIVE OUTCOME OF PENILE VENOUS SURGERY FOR VENOGENIC ERECTILE DYSFUNCTION
}

\author{
CHRISTIAN G. STIEF, MOHAMMAD DJAMILIAN, MICHAEL C. TRUSS, HONKI TAN, \\ WALTER F. THON AND UDO JONAS \\ From the Department of Urology, Medical School Hannover, Hannover, Germany
}

\begin{abstract}
Since penile venous surgery is usually associated with a poor postoperative outcome, a study was done to evaluate possible prognostic factors for this procedure. A total of 77 patients with erectile dysfunction underwent ligation of all dorsal penile veins and resection of the deep dorsal penile vein for venous incompetence. In all patients a comprehensive evaluation was done preoperatively. All patients did not respond to pharmacotherapy and had a venous leak. After a followup of 6 months, patients were classified as having full spontaneous erections, failure and response to pharmacotherapy. Of the 77 patients $31(40.3 \%)$ had full spontaneous erections, $8(10.3 \%)$ were currently responding to pharmacotherapy and $38(49.4 \%)$ failed. The maintenance flow was $75 \pm$ $45 \mathrm{ml}$. per minute in the group with spontaneous erections and $103 \pm 60 \mathrm{ml}$. per minute in the failure group $(\mathrm{p}=0.20)$. Mean patient age was $49.8 \pm 11.7$ and $49.1 \pm 10.2$ years, respectively $(\mathrm{p}=$ 0.23 ). Of the 41 patients with normal single potential analysis of cavernous electrical activity 28 had full erections postoperatively, 5 responded to pharmacotherapy and 8 failed, compared to 3,3 and 30, respectively, of the 36 patients with abnormal single potential analysis of cavernous electrical activity. After a mean followup of 21 months (range 6 to 47 months), 4 patients with full erections at 6 months postoperatively currently require intracavernous pharmacotherapy. Our results indicate that single potential analysis of cavernous electrical activity seems to be an important prognostic factor for the postoperative outcome of penile venous surgery for venogenic impotence.
\end{abstract}

KEY WORDS: impotence, penile erection, veins

Although intracavernous injection therapy ${ }^{1-4}$ and penile prostheses ${ }^{5}$ offer reliable therapeutic options for most patients with erectile dysfunction, these alternatives are often rejected for various reasons. This rejection is reflected by dropout rates of $50 \%$ or more in some longitudinal studies following patients on auto-injection therapy or by low overall acceptance rates of penile prosthesis implantation. Many of these patients indicate that they would like a therapy that restores spontaneous erectile function. For these patients penile reconstruction seems to be an attractive option.

After years of great enthusiasm about cavernous arterialization, ${ }^{6,7}$ mid-term and long-term success rates are disappointing. In addition, significant complications of these procedures have been reported ${ }^{8-10}$ Penile venous operations are also followed by poor long-term results, ${ }^{11-13}$ even when a more aggressive surgical approach is chosen. ${ }^{14-16}$ These observations led to the question of whether penile venous surgery for venogenic impotence is a basically useless procedure or if adequate patient selection has not yet been established. We evaluate the postoperative outcome of 77 consecutive patients with venous leakage who underwent penile venous surgery, thus possibly identifying prognostic factors for the outcome of this procedure.

\section{PATIENTS AND METHODS}

All patients at our impotence clinic undergo a comprehensive approach ${ }^{17}$ regarding the etiology of the erectile dysfunction, including a case history, physical examination, blood laboratory studies, sexual case history (performed by a psychiatrist), single potential analysis of cavernous electrical activity (SPACE), ${ }^{18}$ pharmacological testing ${ }^{17}$ and Doppler ultrasound. ${ }^{19}$ When indicated,${ }^{17}$ patients undergo further examinations, such as cav-

Accepted for publication September 24, 1993

Supported in part by a grant from the Deutsche Forschungsgemeinschaft DFG Sti 96/2-2. ernosometry and cavernosography,$^{20}$ penile angiography or somato-motor and/or autonomic neurological examinations.

If patients do not respond to maximal doses of intracavernous injections ( $30 \mathrm{mg}$. papaverine plus $1 \mathrm{mg}$. phentolamine) plus additional psychogenic or reflexogenic stimulation, they are informed about the high likelihood of venous leakage as a (co)factor for the erectile dysfunction. They also are informed about the implication of this finding with either the alternative of further diagnostics, for example cavernosometry and cavernosography, or other therapeutic strategies, such as vacuum devices, a penile prosthesis or a trial with intracavernous injection of a combination of calcitonin gene-related peptide plus prostaglandin $\mathrm{E} 1 .^{21}$ In patients who choose further diagnostic procedures, cavernosometry and cavernosography are done as described previously..$^{20}$ The maintenance flow is measured after cavernous smooth muscle relaxation is induced by intracavernous injection of $30 \mathrm{mg}$. papaverine plus $1 \mathrm{mg}$. phentolamine, with a flow rate exceeding $14 \mathrm{ml}$. per minute being considered abnormal. ${ }^{22,23}$ If a venous leakage is diagnosed the patients are offered, independently from possibly existing other etiological factors, dorsal penile vein resection or ligation. They are extensively informed about the poor outcome of this procedure and about possible therapeutic alternatives.

From June 1989 to November 1992, 77 patients with erectile dysfunction and documented venous leakage underwent penile venous surgery. Independently from the site of leakage visualized by cavernosography, a longitudinal incision approximately $4 \mathrm{~cm}$. long is made at the base of the penis. Then, all superficial dorsal and lateral penile veins (within Colles' fascia) are doubly ligated and divided. The deep dorsal vein(s) within Buck's fascia is resected from the suspensory ligament to the distal third of the cavernous bodies. Special attention is paid to avoid damage to the dorsal nerves and arteries supplying the glans penis. Cavernous vein ligation is not done. 
All patients are seen at 6 months postoperatively. In patients who report full spontaneous erections no further tests are done. Patients who report results other than full erections are offered pharmacological testing as well as cavernosometry and cavernosography. To evaluate the long-term success of our approach to the management of venous leakage, in May 1993 we sent an extensive questionnaire to all patients with a history of penile venous surgery. Patients and their partners were asked in detail about preoperative and postoperative self-esteem and libido, sexual function, partner relationships (general and sexual), alternative or additional treatments of the (possibly) persistent erectile dysfunction, and possible side effects they relate specifically to the operation. In case of an incomplete response to the questionnaire or if no response was received within 3 weeks, another questionnaire with an individualized cover letter was sent. Again, if no reply was received, the patients were telephoned and either asked to complete the questionnaire or invited on an outpatient basis to reply to the questions personally.

\section{RESULTS}

A total of 77 patients with venogenic erectile dysfunction underwent penile venous surgery between June 1989 and November 1992. All 77 patients were available at 6 months postoperatively and 70 were available for review in May 1993. Followup was 6 to 47 months (mean $21.4 \pm 15$, median 18.5). Patient age was 24 to 72 years (mean $50.1 \pm 13.0$ years). Mean interval since the onset of erectile dysfunction was 4.9 years. Case histories are shown in the table.

There was 1 severe postoperative complication. One patient treated as an outpatient suffered an extensive penile hematoma with subsequent skin necrosis that required multiple plastic revisions and caused significant paresthesia of the glans penis. In 20 patients minor side effects were reported: 7 had mild paresthesia of the penile glans, 6 had minor paresthesia at the incision, 14 had pesistent edema of the prepuce and 5 had a penile deviation.

At 6 months postoperatively 31 patients $(40.3 \%)$ reported full erections with normal intercourse possible, $8(10.3 \%)$ responded to intracavernous papaverine plus phentolamine and $38(49.4 \%)$ failed to achieve full spontaneous or pharmacologically-induced erections. During the extended followup until May 1993, 4 patients with full spontaneous erections at 6 months required intracavernous pharmacotherapy to achieve full erections. These 4 patients reported loss of spontaneous erections after $6(2), 9$ (1) and 24 (1) months postoperatively.

For comparability of the data, the results were analyzed with the outcome at 6 months postoperatively. Mean patient age was $49.8 \pm 11.7$ years (range 24 to 72 years) for those with full erections, $49.1 \pm 10.2$ years (range 27 to 66 years) in the failure group ( $p=0.23$ ) and $56.0 \pm 3.9$ years (range 33 to 67 years) in the pharmacotherapy group. Mean interval since the onset of erectile dysfunction was $4.6,4.7$ and 5.2 years, respectively. Regarding the medical histories, there was no correlation with the postoperative outcome in patients with transurethral resec-

\begin{tabular}{lccc}
\hline \multicolumn{1}{c}{ Case History } & No. & \multicolumn{2}{c}{ Postop. Results } \\
\cline { 3 - 4 } & Pts. & Full Erections & Failures \\
\hline Diabetes mellitus & 8 & 3 & 5 \\
Primary erectile dysfunction & 6 & 1 & 5 \\
Peyronie's disease & 3 & - & 3 \\
Post-transurethral resection of & 4 & 3 & 1 \\
$\quad$ the prostate & 4 & & \\
Intervertebral nucleus prolapse & 3 & - & 4 \\
Kidney transplantation & 3 & - & 2 \\
Radical pelvic surgery & 1 & - & 3 \\
Pelvic ring rupture & 1 & - & 1 \\
Polyneuropathy & 1 & - & 1 \\
Vasculitis & 1 & 1 & - \\
Open prostatectomy & & & 1 \\
\hline
\end{tabular}

tion of the prostate or diabetes mellitus. Patients after radical pelvic surgery or intervertebral disk prolapse, or those with primary erectile dysfunction had a high likelihood of postoperative failure (see table).

The maintenance flow was $75 \pm 45 \mathrm{ml}$. per minute in the group with spontaneous erections, $103 \pm 60 \mathrm{ml}$. per minute in the failure group $(p=0.20)$ and $61.9 \pm 46 \mathrm{ml}$. per minute in the pharmacotherapy group ( $p=0.08$, compared to the success group). Of the 41 patients with normal preoperative SPACE results $28(68.3 \%)$ had full erections postoperatively, $8(19.5 \%)$ failed and $5(12.2 \%)$ responded to pharmacotherapy, compared to $3(8.3 \%), 3(8.3 \%)$ and $30(83.4 \%)$, respectively, of the 36 patients with abnormal preoperative SPACE. When the preoperative SPACE findings are compared in the groups with postoperative full erections or failure, the difference is highly statistically significant (chi-square test, $p<0.001$ ). In May 1993, 42 patients had failed and 21 of these are currently using other treatment options: 13 are on an auto-injection program using a combination of calcitonin gene-related peptide plus prostaglandin $\mathrm{E} 1,5$ received a penile prosthesis and 3 use vacuum devices.

In May 1993, 17 of 70 patients reported an increase in libido, 12 a decrease and 41 no change compared to the preoperative status. Nocturnal or morning erections were improved in 12 patients, worse in 12 and unchanged in 35 . A total of 43 patients would undergo this procedure a second time, 25 would not and 2 were undecided. Of the men treated as outpatients 2 suggested that this procedure should be performed only on an inpatient basis due to postoperative pain that was not adequately managed by the referring physician. Of 5 patients who reported erections sufficient for intercourse but a lack of " $100 \%$ rigidity," the female partners considered the postoperative erection to be "100\%."

\section{DISCUSSION}

At our department venogenic erectile dysfunction is defined as abnormal cavernous drainage, quantified by a maintenance flow in cavernosometry exceeding $14 \mathrm{ml}$. per minute. ${ }^{22-24}$ The decrease in intracavernous pressure during a defined interval may also be considered as a parameter of cavernous venoocclusive dysfunction ${ }^{25}$ but these 2 tests seem to examine the same mechanisms of cavernous occlusion with, as shown by others, consequently similar results in a comparative study. ${ }^{26}$

These quantitative tests of the cavernous occlusive function rely heavily on adequate cavernous smooth muscle relaxation by intracavernous pharmacological application of drugs. ${ }^{20,25} \mathrm{An}$ increased sympathetic tone, for example by stress or anxiety, will cause cavernous smooth muscle contraction with subsequent false-positive cavernosometric results. To minimize this effect, we performed cavernosometry and cavernosography at the end of our evaluation, with the patient having received at least 3 intracavernous injections on different days and, thus, being familiar with diagnostic procedures in this intimate region of the body. Furthermore, the patient is followed throughout the study by the same urologist to obtain his confidence, and cavernosometry and cavernosography are done in an atmosphere as relaxed as possible.

There have been attempts at objective followup after penile reconstruction ${ }^{9,10}$ but in our series only a poor or even no correlation was found between objective data and subjective reports. Since no diagnostic test exists that can discriminate with a high degree of accuracy between normal and abnormal erectile function, it currently is generally accepted that postoperative results of penile reconstruction are best monitored by the patient estimate of the functional result. ${ }^{27}$ To substantiate further the patient personal estimate in this study, we asked the partner for an evaluation of the preoperative and postoperative erectile function.

The underlying etiology of abnormal cavernous veno-occlusive function may be manifold, with factors such as incomplete 
cavernous smooth muscle relaxation due to endothelial or neurotransmitter defects, localized noncompression of sub-tunical or intra-tunical veins, ${ }^{28}$ or cavernous smooth muscle degeneration. ${ }^{29}$ Since cavernous smooth muscle relaxation was induced in our series, as at most other institutions, by pharmacological agents (papaverine) not dependent on endothelial or neurotransmitter function, patients with venous leakage at cavernosometry and cavernosography are most likely to have abnormal cavernous drainage due to either cavernous smooth muscle degeneration, or sub-tunical or intra-tunical venous malcompression.

From a theoretical standpoint, patients with venogenic erectile dysfunction due to cavernous smooth muscle degeneration will not benefit from penile venous surgery, since in that case this procedure does not address the causative mechanism. Penile prosthesis implantation or the use of a vacuum device seems to be the only treatment option left for these patients. However, for patients with a functioning cavernous smooth musculature but a localized defect in the sub-tunical or intratunical venous compression system (and no additional etiologies of the erectile dysfunction), penile venous surgery may be beneficial. In our opinion, these different underlying etiologies of venogenic erectile dysfunction with entirely different causative mechanisms explain the low overall success rate of penile venous surgery for venogenic erectile dysfunction.

Independently from the surgical approach, the mid-term and long-term success rates of penile venous surgery vary between $10 \%$ and $50 \% .^{11-14}$ Our results, with approximately $40 \%$ full spontaneous erections after 6 months and $35 \%$ after 21 months, fit in the frame of the aforementioned experiences. In our opinion these postoperative results are in that low range of success, since the classical diagnostic evaluation of erectile dysfunction with pharmacological testing, Doppler or duplex ultrasonography, and cavernosometry did not allow for a differentiation between the aforementioned 2 main etiologies of venous erectile dysfunction. This is also reflected by the results of our preoperative evaluation, which did not show any correlation of the postoperative results with patient age, duration since onset of erectile dysfunction or maintenance flow. Also, no correlation was found in patients with diabetes mellitus or erectile dysfunction after transurethral resection of the prostate. The only strong correlation in our series was found comparing the preoperative SPACE results (or corpus cavernosum electromyography, as it should now be referred to since the first international meeting on cavernous smooth muscle electromyography in April 1993 at Mannheim, Germany) and the postoperative outcome. Of the 41 patients with normal SPACE results $28(68.3 \%)$ had full erections postoperatively, whereas 30 of $36(83.4 \%)$ with abnormal SPACE findings failed. These data suggest that SPACE has an important role as a prognostic factor for patients with venogenic erectile dysfunction. Impotent patients with normal preoperative SPACE findings combined with venogenic erectile dysfunction are now encouraged at our institution to undergo penile venous surgery, since the likelihood of an improvement in erectile function is $70 \%$ or better. In contrast, patients with venogenic erectile dysfunction and abnormal preoperative SPACE findings are informed about the low success rate of penile venous surgery and are encouraged to choose another treatment option.

Since the introduction of corpus cavernosum electromyography ${ }^{30,31}$ much criticism was raised doubting that the signals recorded were actually electrical activity of cavernous smooth muscle cells or of different origin. In the meantime, experimental studies on isolated cavernous smooth muscle cells ${ }^{32}$ as well as extrinsic recordings of electric activity of cavernous smooth muscle strips ${ }^{33}$ showed a correlation of mechanical and electrical activity of these smooth muscle cells. Furthermore, corpus cavernosum electromyography in animal experiments showed marked differences before and after cavernous denervation. ${ }^{34}$ Although these studies demonstrated the sound scientific bases of corpus cavernosum electromyography, its interpretation and, subsequently, its clinical usefulness still are under debate.

In our study corpus cavernosum electromyography/SPACE was the only predictive diagnostic parameter for penile venous surgery in patients with venogenic erectile dysfunction. For this clinical application of corpus cavernosum electromyography, a differentiation only between normal and abnormal potentials was attempted. Further differentiation, such as myogenic or neurogenic, was avoided since no consensus has yet been reached on this point. However, this discrimination is only of academic interest for the patients with venogenic erectile dysfunction, since the myogenic and neurogenic groups would not benefit from surgery. In contrast, patients with venogenic erectile dysfunction and normal corpus cavernosum electromyography/SPACE findings should have a normal cavernous innervation and a normal smooth musculature with a localized veno-occlusive dysfunction. Theoretically, these patients are likely to benefit from penile venous surgery. The results of our clinical study support these theoretical assumptions and showed that corpus cavernosum electromyography/ SPACE has a predictive value for the postoperative outcome of penile venous surgery in patients with venogenic erectile dysfunction. However, further studies are needed to improve the interpretation of corpus cavernosum electromyography and to confirm our surgical findings.

\section{REFERENCES}

1. Virag, R.: Intracavernous injection of papaverine for erectile failure. Letter to the Editor. Lancet, 2: 938, 1982.

2. Brindley, G. S.: Cavernosal alpha-blockade: a new technique for investigating and treating erectile dysfunction. Brit. J. Psychiatr., 143: 332, 1983.

3. Zorgniotti, A. W. and Lefleur, R. S.: Auto-injection of the corpus cavernosum with a vasoactive drug combination for vasculogenic impotence. J. Urol., 133: 39, 1985.

4. Stackl, W., Hasun, R. and Marberger, M.: Intracavernous injection of prostaglandin E1 in impotent men. J. Urol., 140: 66, 1988.

5. Montague, D. K.: Penile prostheses. An overview. Urol. Clin. N. Amer., 16: 7, 1989.

6. Levine, F. J., Gasior, B. L. and Goldstein, I.: Reconstructive arterial surgery for impotence. Sem. Intervent. Rad., 6: 220, 1990.

7. Goldstein, I.: Penile revascularisation. Urol. Clin. N. Amer., 14: 805, 1987.

8. Schraudenback, L., Klima, M., Kraft, G. and Altwein, J. E.: Problems of penile revascularisation using Hauri's technique. Int. J. Impotence Res., suppl. 2, 4: A134, 1992.

9. Sohn, M. H. H., Sikora, R., Wein, B., Zabelberg, U. and Jakse, G.: Objective follow-up parameters after penile revascularization. Correlations to subjective outcome. J. Urol., part 2, 149: 320A, abstract 431, 1993.

10. Riccardi, R., Jr. and Melman, A.: Objective, long-term results of penile revascularization. J. Urol., part 2, 149: 320A, abstract 429, 1993.

11. Gilbert, P., Sparwasser, C., Beckert, R., Treiber, U. and Pust, R. Venous surgery in erectile dysfunction. The role of dorsal-penilevein ligation and spongiosolysis for impotence. Urol. Int., 49: 40, 1992.

12. Wespes, E., Delcour, C., Preserowitz, L., Herbault, A. G., Strurven, J. and Schulman, C.: Impotence due to corporeal veno-occlusive dysfunction: long-term followup of venous surgery. Eur. Urol., 21: 115, 1992.

13. Freedman, A. L., Costa Neto, F., Mehringer, C. M. and Rajfer, J.: Long-term results of penile vein ligation for impotence from venous leakage. J. Urol., 149: 1301, 1993.

14. Lewis, R. W. and Puyau, F. A.: Procedures for decreasing venous drainage. Sem. Urol., 4: 263, 1986.

15. Lue, T. F.: Penile venous surgery. Urol. Clin. N. Amer., 16:607, 1989.

16. Rossman, B., Mieza, M. and Melman, A.: Penile vein ligation for corporeal incompetence: an evaluation of short-term and ongterm results. J. Urol., 144: 679, 1990.

17. Stief, C. G., Bähren, W., Gall, H. and Scherb, W.: Functional evaluation of penile hemodynamics. J. Urol., 139: 734, 1988.

18. Stief, C. G., Djamilian, M., Schaebsdau, F., Truss, M. C., Schlick, R. W., Abicht, J. H., Allhoff, E. P. and Jonas, U.: Single potential 
analysis of cavernous electric activity - a possible diagnosis of autonomic impotence? World J. Urol., 8: 75, 1990.

19. Jevtich, M. J.: Non-invasive vascular and neurologic tests in use for evaluation of angiogenic impotence. Int. Angiol., 3: 225, 1984.

20. Lue, T. F., Hricak, H., Schmidt, R. A. and Tanagho, E. A.: Functional evaluation of penile veins by cavernosography in papaverine-induced erections. J. Urol., 135: 479, 1986.

21. Djamilian, M., Stief, C. G., Kuczyk, M. and Jonas, U.: Followup results of a combination of calcitonin gene-related peptide and prostaglandin $\mathrm{E} 1$ in the treatment of erectile dysfunction. J. Urol., 149: 1296, 1993.

22. Stief, C. G., Wetterauer, U. and Sommerkamp, H.: Intra-individual comparative study of dynamic and pharmacocavernosography. Brit. J. Urol., 64: 93, 1989.

23. Kromann-Andersen, B., Nielsen, K. K. and Nordling, J.: Cavernosometry: methodology and reproducibility with and without pharmacological agents in the evaluation of venous impotence. Brit. J. Urol., 67: 517, 1991.

24. Vickers, M. A., Jr., Benson, C., Dluhy, R. and Ball, R. A.: The current cavernosometric criteria for corporovenous dysfunction are too strict. J. Urol., 147: 614, 1992.

25. Padma-Nathan, H., Goldstein, I. and Krane, R. J.: Evaluation of the impotent patient. Sem. Urol., 4: 225, 1986.

26. Siegsmund, M., Juenemann, K. P., Schmidt, P., Tschada, R. and Alken, P.: Kavernosometrie: Korrelation zwischen intrakavernösem Druckabfall und Maintenance Flow zur Differentialdiagnose der kavernösen Insuffizienz. Akt. Urol., 22: 366, 1991.
27. Barada, J. H.: The changing role of impotence surgery. State-ofthe-art lecture. J. Urol., part 2, 149: 99A, 1993.

28. Juenemann, K.-P., Lue, T. F., Hellstom, W. G. J., Fournier, G. R. Jr. and Tanagho, E. A.: Hemodynamics of papaverine- and phentolamine-induced penile erections in monkeys and dogs. J. Urol., part 2, 133: 218A, abstract 418, 1985.

29. Mersdorf, A., Goldsmith, P. C., Diederichs, W., Padula, C. A., Lue, T. F., Fishman, I. J. and Tanagho, E. A.: Ultrastructural changes in impotent penile tissue: a comparison of 65 patients. J. Urol., 145: 749, 1991.

30. Gerstenberg, T. C., Nordling, J., Hald, H. and Wagner, G.: Standardized evaluation of erectile dysfunction in 95 consecutive patients. J. Urol., 141: 857, 1989.

31. Wagner, G., Gerstenberg, T. and Levin, R. J.: Electrical activity of corpus cavernosum during flaccidity and erection of the human penis: a new diagnostic method? J. Urol., 142: 723, 1989.

32. Derouet, H., Eckert, R., Ziegler, M. and Trautwein, W.: Cavernosale Einzelzellanalyse glatter cavernöser Muskelzellen von PGE1-Nonrespondern. 11. Symposion für Experimentelle Urologie, Wuppertal, 1992.

33. Stief, C. G., Höppner, C., Jonas, U., Mandrek, K., Noak, T. and Golenhofen, K.: Electrical and mechanical activity of isolated strips from rabbit penile corpus cavernosum. Int. J. Impotence Res., suppl. 2, 4: A36, 1992.

34. Bührle, C. P., Schmidt, P., Juenemann, K. P., Berle, B. and Alken, P.: Automatic acquisition and analysis of EMG data from corpus cavernosum recordings in the dog. Int. J. Impotence Res., suppl. 2, 4: A29, 1992. 